\title{
Arcanobacterium bernardiae
}

National Cancer Institute

\section{Source}

National Cancer Institute. Arcanobacterium bernardiae. NCI Thesaurus. Code C86148.

A species of facultatively anaerobic, gram positive, coccobacilli shaped bacteria assigned to the phylum Actinobacteria. This bacteria is non-motile, non spore forming, catalase negative, does not hydrolyze esculin or urea and ferments glycogen, erythritol and ribose. A. bernardiae has only been found in humans, and is associated with urinary tract infections and septic arthritis. 